\title{
Chapter 10 \\ Remote Sensing of Geodiversity as a Link to Biodiversity
}

\author{
Sydne Record, Kyla M. Dahlin, Phoebe L. Zarnetske, Quentin D. Read, \\ Sparkle L. Malone, Keith D. Gaddis, John M. Grady, Jennifer Costanza, \\ Martina L. Hobi, Andrew M. Latimer, Stephanie Pau, Adam M. Wilson, \\ Scott V. Ollinger, Andrew O. Finley, and Erin Hestir
}

\subsection{Conserving Nature's Stage}

Biodiversity is essential for ecosystem functioning and ecosystem services (Chapin et al. 1997; Yachi and Loreau 1999). Yet rapid global change is altering biodiversity and endangering its vital functions, with human-caused habitat deterioration being the number one cause of biodiversity loss (Sala et al. 2000). In addition, climate change is directly affecting individual species abundances and distributions and indirectly affecting species via biotic interactions (Walther et al. 2002). When combined, these effects lead to novel ecological communities for which there are no modern analogs (Williams and Jackson 2007). Although species have continually experienced shifts in climate, the recent rate of temperature change is more rapid than in any other timeframe in the past 10,000 years (Marcott et al. 2013), and temperatures are expected to rise even faster in the near future (Smith et al. 2015). In light of these rapid global changes, a major challenge for biodiversity scientists is to generate robust statistical models that describe and predict biodiversity in space and

\footnotetext{
S. Record $(\bowtie)$

Department of Biology, Bryn Mawr College, Bryn Mawr, PA, USA

e-mail: srecord@brynmawr.edu

K. M. Dahlin

Department of Geography, Environment, \& Spatial Sciences, Michigan State University,

East Lansing, MI, USA

Ecology, Evolutionary Biology, and Behavior Program, Michigan State University,

East Lansing, MI, USA
}

P. L. Zarnetske · Q. D. Read

Ecology, Evolutionary Biology, and Behavior Program, Michigan State University,

East Lansing, MI, USA

Department of Integrative Biology, Michigan State University, East Lansing, MI, USA

J. Cavender-Bares et al. (eds.), Remote Sensing of Plant Biodiversity,

https://doi.org/10.1007/978-3-030-33157-3_10 
time, from which changes in hot spots (highs) and cold spots (lows) of biodiversity may indicate shifts in ecosystem functions and services.

Contemporary strategies for addressing and managing biodiversity loss align with a metaphor developed by G. Evelyn Hutchinson in his book The Ecological Theater and the Evolutionary Play from Shakespeare's As You Like It (Hutchinson 1965). In Act II, Scene VII, of As You Like It, Shakespeare wrote, "All the world's a stage, and all the men and women merely players. They have their exits and their entrances." In Hutchinson's metaphor, the world's biota comprises the players, and the script is an evolutionary play. More recently, the metaphor has been extended to consider the Earth's abiotic setting as the stage (Beier et al. 2015).

Conservation efforts often emphasize management plans for the actors [e.g., Essential Biodiversity Variables (EBVs)] (Fernandez and Pereira, Chap. 18).

\author{
S. L. Malone \\ Department of Biological Sciences, Florida International University, Miami, FL, USA \\ K. D. Gaddis \\ National Aeronautics and Space Administration, Washington, D.C., USA \\ J. M. Grady \\ Department of Biology, Bryn Mawr College, Bryn Mawr, PA, USA \\ Ecology, Evolutionary Biology, and Behavior Program, Michigan State University, \\ East Lansing, MI, USA \\ Department of Integrative Biology, Michigan State University, East Lansing, MI, USA \\ J. Costanza \\ Department of Forestry and Environmental Resources, NC State University, \\ Research Triangle Park, NC, USA \\ M. L. Hobi \\ Swiss Federal Research Institute WSL, Birmensdorf, Switzerland \\ SILVIS Lab, Department of Forest and Wildlife Ecology, University of Wisconsin-Madison, \\ Madison, WI, USA
}

A. M. Latimer

Department of Plant Sciences, UC Davis, Davis, CA, USA

S. Pau

Department of Geography, Florida State University, Tallahassee, FL, USA

A. M. Wilson

Geography Department, University at Buffalo, Buffalo, NY, USA

S. V. Ollinger

Department of Natural Resources and the Environment, University of New Hampshire, Durham, NH, USA

A. O. Finley

Department of Geography, Environment, \& Spatial Sciences, Michigan State University,

East Lansing, MI, USA

Department of Forestry, Michigan State University, East Lansing, MI, USA

E. Hestir

School of Engineering, University of California, Merced, CA, USA 
For instance, the US Endangered Species Act and International Union for Conservation of Nature (IUCN) Red List focus on individual species (ESA 1973; IUCN 2001). However, an inherent challenge to managing species is that, during the course of a play, the actors move across the stage. Geo-referenced fossils from the paleoecological record provide evidence of how species' geographic ranges shifted in the past as Earth's climate fluctuated (Williams and Jackson 2007; Veloz et al. 2012). For instance, in terms of estimating EBVs (Fernandez and Pereira, Chap. 18), species distribution models (SDMs) are one of the most common tools for understanding how species ranges might shift over time and space (Elith and Leathwick 2009; Record and Charney 2016), but they are fraught with statistical (Record et al. 2013) and biological shortcomings (Belmaker et al. 2015; Charney et al. 2016; Evans et al. 2016) that hamper their ability to reliably inform management. Given the challenges of managing species whose ranges might be shifting in response to climate change (Veloz et al. 2012), there is interest in focusing conservation efforts on areas that are likely to support biodiversity and on the processes that generate it (Pressey et al. 2007; Anderson and Ferree 2010; Beier and Brost 2010). Indeed, The Nature Conservancy, one of the world's leading nonprofit conservation organizations, has adopted the rallying cry of "conserving nature's stage" (Beier et al. 2015). Conserving nature's stage entails identifying parcels of Earth that are valuable for their geodiversity and for their capacity to support diverse life forms today and into the future.

Geodiversity has been defined in several ways (see Table 1.2 in Gray 2013). Some definitions of geodiversity refer to variability in soil, geological, and geomorphological features and the processes that give rise to them (Gray 2013 and references therein). Other definitions tend to have a wider scope and also include topography, hydrology, and climate (Benito-Calvo et al. 2009; Parks and Mulligan 2010). These more inclusive definitions of geodiversity capture variability in the entire geosphere (Hjort et al. 2012) that link to important drivers of biodiversity (e.g., energy, water, and nutrients (Richerson and Lum 1980; Kerr and Packer 1997)). The geosphere includes the lithosphere, atmosphere, hydrosphere, and cryosphere (Williams 2012) and processes within and among them and encompasses the abiotic components of Earth's "Critical Zone," or the portion of Earth where biotic and abiotic processes support life on Earth's surface (NRC 2001). Just as the Critical Zone arises from interactions among abiotic and biotic processes, geodiversity is not separated from biotic influences and biodiversity. A key step in the prioritization of conservation areas using this approach is to understand the relationships between biodiversity and geodiversity. Remotely sensed biodiversity and geodiversity data have the potential to answer questions of scale to better inform conservation decisions because they can provide coverage at nearly continuous large spatial extents (i.e., regional to global) and at fine spatial and temporal resolutions (Fig. 10.1 for a spatial example). Here, we provide an overview of remotely sensed data sources that can be used to measure geodiversity and biodiversity to better understand biodiversity-geodiversity relationships, which is a key step in conserving nature's stage. 

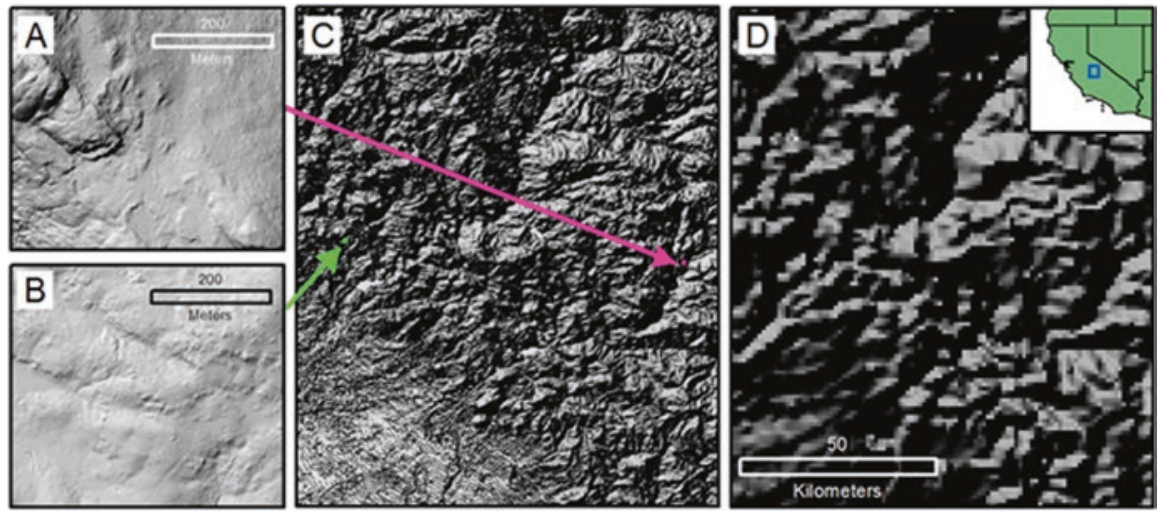

Fig. 10.1 Topography at different spatial grains. Hillshade maps calculated from digital elevation models (DEMs) at $1 \mathrm{~m}$ resolution (a) and (b), $90 \mathrm{~m}$ resolution (c), and $1 \mathrm{~km}$ resolution (d). The inset map in (d) shows the locations of panels (c) and (d) in California, which have the same extent. Data for panels (a) and (b) are from the National Ecological Observatory Network's (NEON) Airborne Observation Platform Light Detection and Ranging (LiDAR) system (Kampe et al. 2010). Data for panels (c) and (d) are from the Shuttle Radar Topography Mission (SRTM) via earthenv.org (Robinson et al. 2014)

\subsection{Geodiversity Indices}

Geodiversity represents an opportunity for habitat differentiation (Radford 1981) and available niche space (Dufour et al. 2006) that is thought to support biodiversity (Gray 2008). The continuous nature of remote sensing (RS) data enables exploration of novel measures of geodiversity. In this section we focus our discussion on metrics of variability, although absolute values (e.g., minimum and maximum thresholds) of some geographical features are also informative for understanding species' limits and ultimately species diversity. Studies have used two aspects of variability: the absolute range of conditions and the spatial configuration of these conditions (Spehn and Körner 2005; Dufour et al. 2006; Jackova and Romportl 2008; Serrano et al. 2009; Hjort and Luoto 2010; Hjort and Luoto 2012). The range in conditions is an estimate of the different elements in the area of interest. Given sampling units larger than the minimum pixel resolution, the proportional area covered by distinct geographical features could be used to calculate an evenness index of geodiversity. Categorical features have also treated geodiversity variables similarly to species with measured presences or abundances in various geodiversity metrics (Serrano et al. 2009; Tuanmu and Jetz 2015).

Alternatively, geodiversity could be quantified as variability in continuous observations such as elevation or climate. A focus on variability allows for different geological contexts (past and present) to be taken into account. One of the most common measures of environmental heterogeneity is elevational range (Stein et al. 2014), simply the absolute difference between elevation at two sites or sample units (i.e., among or within sites, respectively). Using elevation as an example, the average 
difference, squared, between the elevation in a focal cell and all other cells in a sample unit could be used as a measure of topographic heterogeneity. The coefficient of variation is a similar measure of heterogeneity, though it is standardized to the mean elevation of the sample unit. Pairwise site differences in multiple geographical features can be used as predictors in matrix regression such as generalized dissimilarity models (Ferrier et al. 2007) or more generally a Mantel test (Tuomisto et al. 2003; Legendre et al. 2005), though mechanistic interpretation is limited when geographical features are combined in this way.

Additional approaches include a geodiversity atlas that classifies areas as having very high, high, moderate, low, and very low geodiversity (Kozlowski 1999), quantifying geodiversity in terms of total component resource potential (i.e., energy, water, space, and nutrients; Parks and Mulligan 2010), and the geodiversity index (Gd) that relates the variety of physical elements (i.e., geomorphological, hydrological, soils) with the roughness and surface of the previously established geomorphological units according to the formula:

$$
G d=\frac{E g R}{\ln S}
$$

where Eg is the number of different physical elements, $R$ is the coefficient of roughness of the unit, and $S$ is the surface of the unit $\left(\mathrm{km}^{2}\right)$. The $\mathrm{Gd}$ is a semiquantitative scale that permits the establishment of five values of geodiversity, from very low to very high for each homogeneous unit. It is argued that use of Gd would allow easier comparison of units and aid suitable management of protected areas (Serrano et al. 2009; Hjort and Luoto 2010; Tukiainen et al. 2017).

With continuously measured remotely sensed geographical features, the sample unit (i.e., grain size) can be modified to examine within site and total site (and thus between sites) geodiversity. Additionally, RS data can uniquely address how relationships between geodiversity and biodiversity change across scales. Various combinations of changing grain and extent (change grain maintain extent, change extent maintain grain, change grain and extent) could be examined to explore scaling relationships (Barton et al. 2013).

\subsection{Remote Sensing of Geodiversity}

In the following sections, we describe the different components of geodiversity (Table 10.1), some of the ways they can be quantified, and the current state of technologies available to measure them remotely via airborne or satellite observations (Table 10.2). To match current interests in global biodiversity databases (e.g., the Global Biodiversity Information Facility, gbif.org), and because of the importance of scaling from local to much larger extents, we focus here on globally available data; however, we also mention some local scale RS applications. In particular, given that more and more remotely sensed data have been made publically available, we highlight open access remotely sensed geodiversity data. 
Table 10.1 Elements of geodiversity

\begin{tabular}{|c|c|c|c|}
\hline \multirow[t]{13}{*}{ Lithosphere } & \multirow[t]{4}{*}{ Geology } & \multicolumn{2}{|l|}{ Minerals } \\
\hline & & \multicolumn{2}{|l|}{ Rocks } \\
\hline & & \multicolumn{2}{|c|}{ Unconsolidated solids } \\
\hline & & \multicolumn{2}{|c|}{ Fossils } \\
\hline & Geomorphology & \multicolumn{2}{|c|}{ Tectonics } \\
\hline & \multirow[t]{2}{*}{ Soils } & \multicolumn{2}{|c|}{ Soil chemical properties } \\
\hline & & \multicolumn{2}{|c|}{ Soil physical properties } \\
\hline & \multirow[t]{6}{*}{ Topography } & \multicolumn{2}{|l|}{ Elevation } \\
\hline & & \multicolumn{2}{|c|}{ Landforms (e.g., ridges, spurs) } \\
\hline & & \multicolumn{2}{|l|}{ Slope } \\
\hline & & \multicolumn{2}{|l|}{ Aspect } \\
\hline & & \multicolumn{2}{|l|}{ Energy } \\
\hline & & \multicolumn{2}{|l|}{ Roughness } \\
\hline \multirow[t]{3}{*}{ Atmosphere } & \multirow[t]{3}{*}{ Climate and weather } & Temperature & Extreme events \\
\hline & & Precipitation & \\
\hline & & Wind & \\
\hline \multirow[t]{2}{*}{ Hydrosphere } & \multicolumn{3}{|l|}{ Surface water } \\
\hline & \multicolumn{3}{|l|}{ Groundwater } \\
\hline \multirow[t]{2}{*}{ Cryosphere } & \multicolumn{3}{|l|}{ Ice } \\
\hline & \multicolumn{3}{|l|}{ Snow } \\
\hline
\end{tabular}

Adapted from Serrano et al. (2009)

Table 10.2 Examples of remotely sensed geodiversity elements

\begin{tabular}{|c|c|c|}
\hline Geosphere & $\begin{array}{l}\text { Geodiversity } \\
\text { element }\end{array}$ & RS data set \\
\hline \multirow[t]{4}{*}{ Lithosphere } & Geology & Ground-penetrating radar (GPR) \\
\hline & \multirow[t]{3}{*}{ Topography } & $\begin{array}{l}\text { Advanced Spaceborne Thermal Emission and Reflection } \\
\text { Radiometer (ASTER) }\end{array}$ \\
\hline & & Shuttle Radar Topography Mission (SRTM) \\
\hline & & Sentinel-2 \\
\hline \multirow[t]{7}{*}{ Atmosphere } & \multirow[t]{3}{*}{$\begin{array}{l}\text { Surface } \\
\text { temperature }\end{array}$} & $\begin{array}{l}\text { MODIS (Moderate Resolution Imaging Spectroradiometer) } \\
\text { surface temperature }\end{array}$ \\
\hline & & $\begin{array}{l}\text { AVHRR (Advanced Very High Resolution Radiometer) } \\
\text { surface temperature }\end{array}$ \\
\hline & & Sentinel-3 \\
\hline & \multirow[t]{2}{*}{ Rainfall } & Tropical Rainfall Measurement Mission (TRMM) \\
\hline & & Global Precipitation Measurement (GPM) mission \\
\hline & \multirow{2}{*}{$\begin{array}{l}\text { Wind direction } \\
\text { and speed }\end{array}$} & Quick Scatterometer (QuickSCAT) \\
\hline & & Rapid Scatterometer (RapidScat) \\
\hline \multirow[t]{3}{*}{ Hydrosphere } & \multirow[t]{2}{*}{ Soil moisture } & ESA's Soil Moisture and Ocean Salinity (SMOS) \\
\hline & & NASA's Soil Moisture Active Passive (SMAP) observatory \\
\hline & Gravity anomalies & Gravity Recovery and Climate Experiment (GRACE) \\
\hline Cryosphere & $\begin{array}{l}\text { Ice sheet mass } \\
\text { balance }\end{array}$ & $\begin{array}{l}\text { Geoscience Laser Altimeter System (GLAS) sensor onboard } \\
\text { the Ice, Cloud, and land Elevation Satellite (ICESat) }\end{array}$ \\
\hline
\end{tabular}




\subsubsection{Lithosphere}

\subsubsection{Lithosphere: Topography}

Topographic barriers can influence geographic patterns of biodiversity by physically isolating populations of plants and animals (Janzen 1967). Topography also can be used as an indirect measure of microclimate, as topographic position can influence temperature and precipitation (e.g., Ollinger et al. 1995). Topography of the lithosphere crust is often represented by elevation (the height above sea level of a given point on the ground) or bathymetry (the depth to the bottom of a water body). In February 2000 the SRTM radar system flew on the US Space Shuttle Endeavour for 11 days collecting radar-derived elevation data from $60^{\circ} \mathrm{N}$ to $56^{\circ} \mathrm{S}$. These data were originally released at $90 \mathrm{~m}$ resolution; however, in 2015, $30 \mathrm{~m}$ data (1 arc second) were released for the entire SRTM extent. There are many other sources of elevation data including NASA Advanced Spaceborne Thermal Emission and Reflection Radiometer ASTER (Fig. 10.2), active radar satellites designed for ice measurement (see the Cryosphere section), and more. NASA is currently working to develop a best available digital elevation model (DEM) for the planet, NASADEM. For this the entire SRTM data set will be reprocessed, Geoscience Laser Altimeter System (GLAS) data will be incorporated to remove artifacts, and the Advanced Spaceborne Thermal Emission and Reflection Radiometer Global Digital Elevation Model version 2 (ASTER) and Global Digital Elevation Map (GDEM) V2 DEMs will be used for refinement.

Elevation is only one of many products under the umbrella of topography. Slope (the angle between two elevation points) and aspect (the direction a slope is facing) are two of the many indices that can be derived from elevation data. Importantly, most of these indices are kernel-dependent, meaning they rely on data not just from an individual point but from surrounding points as well. For example, ArcGIS 10.3 (ESRI; Redlands, California) calculates the slope of a given pixel (elevation value) as the maximum slope between that center pixel and the eight surrounding pixels. The "terrain" function in the raster package in R statistical software (Hijmans and van Etten 2019) permits several different methods for calculating slope based on either a 4- or an 8-cell kernel, and these calculations differ slightly from those in the Geospatial Data Abstraction Library (GDAL; gdal.org). Environment for Visualizing Images (ENVI) software (Harris Geospatial Solutions, Broomfield, Colorado) allows the user to select any kernel size then fits a quadratic surface to the entire kernel, calculating slope and other parameters based on that surface (Wood 1996). These different methods could lead to somewhat different results; in particular, the selection of a small versus a large kernel could change the slope estimated. Imagine, for example, with fine-grained data, the inside of a tip-up pit on the side of a northfacing slope. The local aspect could be south facing, while a larger kernel could reveal that the landscape is north facing.

Beyond slope and aspect, there are many other kernel-dependent topographic measures. For instance, Topographic Position Index (TPI) is defined as the difference between a central pixel and the mean of its surrounding pixels. Terrain 


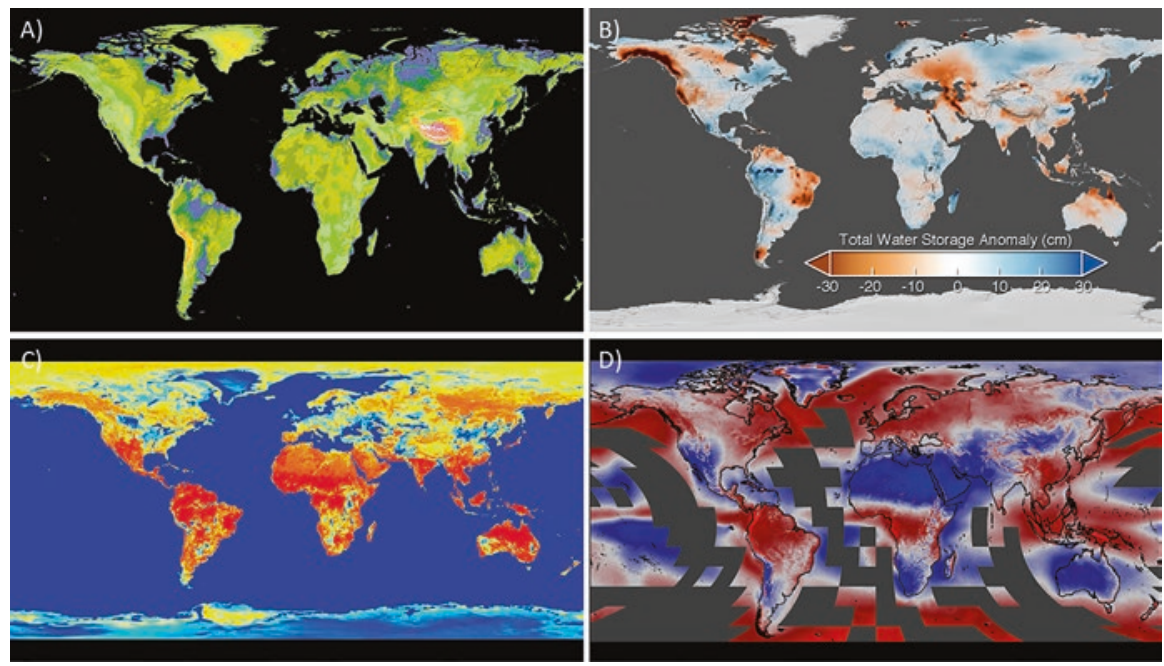

Fig. 10.2 Four examples of geodiversity variables derived from National Aeronautics and Space Administration (NASA) data products. (a) Earth's elevation, from which topographic diversity can be calculated, from 2009 imagery from the Advanced Spaceborne Thermal Emission and Reflection Radiometer (ASTER) instrument aboard NASA's Terra satellite (30 m spatial resolution). Image courtesy of NASA/JPL/METI/ASTER Team, NASA's Goddard Space Flight Center. https://svs. gsfc.nasa.gov/11734. Elevation in meters shown with yellows being lower in elevation than greens or reds. (b) Gravity Recovery and Climate Experiment's (GRACE) Terrestrial Water Storage Anomaly as of April 2015 relative to a 2002-2015 mean. Image courtesy of NASA's Scientific Visualization Studio ( $1^{\circ}$ spatial resolution). (c) Soil Moisture Active Passive (SMAP) global radiometer map. Image courtesy of NASA (9 km spatial resolution). H-polarized brightness temperatures are shown in degrees Kelvin with warmer colors (reds and oranges) showing warmer temperatures and cooler colors (blues and yellows) showing cooler temperatures. (d) Mean annual cloud frequency (\%; reds indicate higher cloud frequency than blues) over 2000-2014 derived from NASA's Moderate Resolution Imaging Spectroradiometer (MODIS) satellites (Wilson and Jetz 2016; 1 km spatial resolution)

Ruggedness Index (TRI), in contrast, is the mean of the difference between the central pixel and its surrounding pixels (Riley et al. 1999). Wood (1996) describes a number of convexity and curvature metrics based on the first and second derivatives of the quadratic surface described above. DEMs can also be classified into topographic features or landforms like peaks, ridges, channels, and pits, though these definitions depend on specific threshold values that may either be prescribed by software or defined by the user. Incident solar radiation can also be calculated for a given day or aggregated for a year based on a given point's elevation and latitude and the elevations of surrounding pixels. Although this section mainly describes DEM-derived morphometric landforms, it is also important to acknowledge that the genesis of landforms interacts with the ecology of a system. For instance, two hills with similar shapes may have very different associated vegetation if one is sandy (e.g., a dune) and the other is made of tills (e.g., end moraine).

While SRTM-derived products are typically used to produce "best available" topographic information, a challenge with SRTM is that the mission occurred 
only once. In geologically and tectonically active areas and areas where humans are influencing geology, satellite-derived data can be used to detect even very small changes over time. For example, Ge et al. (2014) used synthetic aperture radar (SAR) interferometry to detect subsidence in the Bandung Basin (Indonesia) likely due to groundwater extraction. Yun et al. (2015) used SAR data to map areas of change and potential damage after the 2015 Gorkha earthquake in central Nepal. Using SAR instruments in concert with LiDAR instruments on airborne flights has allowed for greater than $30 \mathrm{~cm}$ vertical accuracy (Corbley 2010). The launch of the Global Ecosystem Dynamics Investigation (GEDI) mission onboard the International Space Station has the potential to allow for improved global topographic data (Stavros et al. 2017).

\subsubsection{Lithosphere: Geology and Soils}

Geology consists of several subdisciplines, including lithology, tectonics, volcanology, and seismology. A modern geologic "map" in a geographic information system (GIS) framework may include polygons outlining the different substrate types and their ages, lines showing faults, and points identifying small outcrops or places where cores were collected. These static (unchanging through time) representations are developed through the painstaking work of geologists who gather in-situ records of rock type and estimates of geologic feature extents. Geologic maps vary in quality and access due largely to the density and biases of field technicians. When considering long-term evolutionary histories that generate deeper phylogenetic patterns, geological processes of uplift and erosion can become important (Cowling et al. 2009). Nevertheless, for more historically proximate species, community assembly, the available minerals, substrate structure, and topography are likely to play a more important role, especially in plants. For example, although all locations across the Mauna Loa environmental matrix in Hawai'i share a common parent material, differences in age, texture, and nutrient availability (due to variation in climate and weathering) lead to dramatically different vegetation patterns (Vitousek et al. 1992).

Similar to geologic maps, soil maps are typically developed through fieldwork and image interpretation for a single time period. Nevertheless, soils have higher spatial variability than bedrock and may change rapidly in response to natural or man-made disturbance. Recently there have been calls to improve the quality and dynamism of soil maps (Grunwald et al. 2011). The SoilGrids $1 \mathrm{~km}$ data product (Hengl et al. 2014) is one such example. It is a modeled product that relies on indirect remotely sensed variables, such as Moderate Resolution Imaging Spectroradiometer (MODIS), leaf area index (LAI), land surface temperature (LST), and topography from the SRTM to produce estimates at six depths of soil organic carbon, soil $\mathrm{pH}$, sand, silt, and clay fractions, bulk density, cation-exchange capacity, coarse fragments, and depth to bedrock.

Imaging spectroscopy has been broadly applied for geologic mapping (Goetz et al. 1985; Gupta 2013). Multispectral imagery, like NASA's ASTER instrument and the European Space Agency's (ESA's) Sentinel-2 satellite, that is part of the 
Copernicus program has long been used for mapping lithography in exposed surface environments (Rowan and Mars 2003; Hewson et al. 2005; Massironi et al. 2008; van der Werff and van der Meer 2016). Hyperspectral imagery has been used successfully to map minerals in many low-vegetation landscapes. For example, the Hyperion sensor, aboard the now decommissioned EO-1 satellite, was used to map mineralogy in Australia (Cudahy et al. 2001). The Airborne Visible/Infrared Imaging Spectrometer (AVIRIS) and new AVIRIS-Next Generation missions continue to push the boundary of imaging spectroscopy used in mineral mapping (Krause et al. 1993; Crowley 1993; Green et al. 1998). These instruments can also provide information on soil nutrient availability in areas dominated by vegetation cover via the influence of soils on foliar chemistry (e.g., Ollinger et al. 2002).

Ground-based RS has also provided insights for subsurface geologic mapping. For instance, ground-penetrating radar (GPR) uses radar pulses to map the relative densities of materials belowground and effectively maps soil and bedrock in layers (Davis and Annan 1989). Airborne GPR can greatly enhance the temporal and spatial resolution of geologic maps (Catapano et al. 2014; Campbell et al. 2018).

\subsubsection{Atmosphere: Climate and Weather}

Climate is an important control on mineral weathering, soil formation, and landforms (Jenny 1941). Surface temperature and cloud cover are readily observed with RS. The Advanced Very High Resolution Radiometers [AVHRR; National Oceanographic and Atmospheric Administration (NOAA)] have been collecting surface radiation data in the visible, infrared, and thermal spectra with twice-daily global coverage since 1981 that currently gathers data at $\sim 1 \mathrm{~km}$ spatial resolution. AVHRR data can be used to map cloud cover and land and water surface temperatures; however, changes in satellite technology and the lack of onboard calibration in the AVHRR sensors have made the use of these data challenging due to a need for standardization of data across satellite technologies (Cao et al. 2008). The launch of the MODIS sensors on NASA's Terra (launched in 1999) and Aqua (launched in 2002) satellites and ESA's Sentinel-3 satellite as part of the Copernicus program (3-A launched in 2016 and 3-B launched in 2018) significantly improved global mapping capabilities. The two MODIS sensors map most of the planet twice a day with 36 bands ranging from the visible to the thermal infrared. The MODIS bands were selected to capture properties of the land surface but also ocean properties, atmospheric water vapor, surface temperature, and clouds (Fig. 10.2). Products from MODIS, such as surface temperature and cloud presence, have been used either to directly map climate variables for use in ecological research (e.g., Cord and Rödder 2011; Wilson and Jetz 2016) or to inform modeled climate products like Worldclim-2 (Fick and Hijmans 2017). Furthermore, surface temperature can better characterize plant ecological differences (Still et al. 2014) because it more accurately captures canopy temperature, which is not the same as air temperature, and because many air temperature products (such as Worldclim-2) are interpolated (see Pinto-Ledézma and Cavender-Bares, Chap. 9). 
Satellite-derived rainfall products are estimated through a combination of measurements, including surface reflectance of clouds (i.e., cloud coverage, type, and top temperature), passive microwave (i.e., column precipitation content, cloud water and ice, rain intensity and type), and lightning sensors. The Tropical Rainfall Measurement Mission (TRMM) operated from 1997 to 2015, providing information on rainfall amount and intensity and lightning activity globally every 3 hours at $5 \mathrm{~km}$ resolution from $38^{\circ} \mathrm{N}$ to $38^{\circ} \mathrm{S}$. As a follow-up to TRMM, the Global Precipitation Measurement (GPM) mission relies on a constellation of satellites, including a core GPM observatory, to produce $0.1^{\circ}$ resolution data every 30 minutes from $60^{\circ} \mathrm{N}$ to $60^{\circ} \mathrm{S}$. Initiated in 2014 , GPM allows new explorations of extreme weather events. Like MODIS temperature measurements, TRMM and GPM precipitation measures have been directly incorporated into ecological research (e.g., Deblauwe et al. 2016) and used to inform modeled climate products like the Climate Hazards Group Infrared Precipitation with Station data product (CHIRPS; Funk et al. 2015).

There is also a broad set of efforts to generate reanalysis products that combine the history of Earth observations to develop temporally and spatially consistent global models of climatic and environmental variables. For instance, the NASA Modern-Era Retrospective Analysis for Research and Applications (MERRA) models close to 800 radiative and physical properties of the Earth's atmosphere at 3- to 6-hour time steps from 1979 to present at $\sim 50 \mathrm{~km}$ spatial resolution (Rienecker et al. 2011). While this obviously sacrifices spatial resolution, these efforts open the door for longer-term analysis of climatic influence on biologic phenomena.

One commonly overlooked source of geologic substrate lies in the atmosphere. Airborne dust particles provide an essential source of nutrients in many environments and can originate from sources hundreds to thousands of miles away (Chadwick et al. 1999). Aeolian transport of phosphorus from North Africa to South America is thought to be an important driver of Amazonian productivity (e.g., Okin et al. 2004). Studies have mapped dust sources and rates using MODIS products (Ginoux et al. 2012) and produced 3-D models of dust transportation using LiDAR on the Cloud-Aerosol Lidar and Infrared Pathfinder Satellite Observation (CALIPSO) satellite (Yu et al. 2015). Furthermore, the SeaWinds instrument on the Quick Scatterometer (QuickSCAT) satellite and the subsequent Rapid Scatterometer (RapidSCAT) aboard the International Space Station measures wind speed and direction over the ocean's surface.

\subsubsection{Hydrosphere}

The hydrosphere consists of the water on, in, and above Earth's surface and is known to have a large influence in structuring riparian and aquatic communities of organisms (reviewed by Atkinson et al. 2017). The hydrosphere interacts with other types of geodiversity in the lithosphere, cryosphere, and atmosphere. Topography alone can be used to indirectly provide a crude estimate of many hydrological 
variables, including watershed size, soil water content (Moore et al. 1991), flow paths, and surface water. In addition, two types of satellite data can be used to estimate soil moisture and groundwater, which in some systems are important drivers of plant diversity because drought sensitivity may shape plant distributions (e.g., Engelbrecht et al. 2007). The ESA's Soil Moisture and Ocean Salinity (SMOS; launched 2009) and NASA's Soil Moisture Active Passive observatory (SMAP; launched 2015; Fig. 10.2) both use microwave radiometers to detect surface soil moisture globally in areas with low topographic variation and low-vegetation cover. The Gravity Recovery and Climate Experiment (GRACE; launched in 2002; Fig. 10.2) is a pair of satellites that measure gravity anomalies around the world, allowing researchers to estimate available groundwater reserves and their change over time.

Water quality is a critical driver of aquatic biodiversity across taxa, from plants to animals (Stendera et al. 2012). Watershed disturbance, sediment runoff, and nutrient pollution are major aquatic biodiversity stressors, affecting phytoplankton and aquatic and wetland vegetation abundance and diversity (Lacoul and Freedman 2006; Mouillot et al. 2013) and higher trophic levels (e.g., zooplankton, shrimps, larval fish, and birds (Thackeray et al. 2010). Optical RS can be used to retrieve a limited but important set of water quality variables, including particulate and dissolved organic and inorganic matter, chlorophyll-a, as well as other phytoplankton pigments like the phycocyanins common in potentially harmful cyanobacteria blooms. Surface or "skin" water temperature is measured from instruments with thermal bands (Giardino et al. 2018; Alcântara et al. 2010). The major limitation in RS of water quality is in sensor resolution. Sensors must have a fine enough pixel size to resolve water bodies, with high enough radiometric sensitivity to detect small changes in a dark target (10\% or less of the total signal received by the sensor, Muller-Karger et al. 2018; Hestir et al. 2015). While some water quality products are publically distributed with limited spatial coverage [e.g., United Nations Educational, Scientific and Cultural Organization (UNESCO) regions], free data processors distributed by NASA (Sea-viewing Data Analysis System [SeaDAS]) and the ESA (Sentinel Application Platform) enable users to compute their own water quality products.

\subsubsection{Cryosphere}

Earth's fossil record illustrates how changes in glacial cover over time have governed the distribution of biodiversity (e.g., Veloz et al. 2012), and many aspects of the globe's biodiversity are influenced by snow, ice, and permafrost (reviewed by Vincent et al. 2011). The frozen parts of the Earth system, the cryosphere, can be detected with a number of different RS tools. The cryosphere can be divided into several different components-seasonally snow-covered land, permafrost, glaciers and ice sheets, lake ice, and sea ice. Because cloud cover is a frequent problem at high latitudes, cryosphere RS often relies on longwave techniques that can pass 
through clouds. A recent book, Remote Sensing of the Cryosphere (Tedesco 2014), describes these tools and methods in great detail; here we review some of the major techniques. In all of the discussion below, the importance of change over time is paramount; inter- and intra-annual variation in snow and ice cover are important drivers of physical and biological processes.

The 3-D extent of snow and ice can easily be mapped using optical techniques; snow reflects strongly in the visible and near-infrared (NIR) range but absorbs in the shortwave infrared (SWIR), making it spectrally distinct from other white objects such as rooftops and clouds. These distinctions may still be challenging with multispectral sensors, but hyperspectral sensors permit mapping of snow versus clouds and even some estimation of snow particle size (e.g., Burakowski et al. 2015). Passive microwave sensors can be used to estimate snow depth and snow water equivalent, while active microwave sensors can map liquid water content. Tools and techniques for mapping snow are reviewed by Dietz et al. (2011).

Ice and permafrost features can be mapped with many of the tools and methods described in preceding sections. Snow cover can be mapped using optical sensors and methods; subsidence of the cryosphere can be mapped with SRTM (near global extent, 30-90 m spatial resolution, single snapshot in time) and SAR (airborne, $2 \mathrm{~m}$ spatial resolution); and passive microwave radiometers such as SMOS (global extent, $50 \mathrm{~km}$ spatial resolution, 3-day temporal resolution) and SMAP (near global extent for low-vegetation areas, 9-36 km spatial resolution, 8-day temporal resolution) can be used to map frozen versus thawed ground surfaces (Entekhabi et al. 2014). Because glaciers and ice sheets are fundamentally a combination of snow, ice, and liquid water, many of the techniques described above, such as optical sensors and passive microwave radiometers, can be used to map their extent and status. In addition, the GLAS sensor onboard the Ice, Cloud, and land Elevation Satellite (ICESat; near global spatial extent, $70 \mathrm{~m}$ spatial resolution, 91-day temporal resolution from 2003 to 2009) permitted the mapping of ice sheet mass balance (Zwally et al. 2011). ICESat-2 is scheduled for launch in 2018 (global spatial extent, $14 \mathrm{~km}$ spatial resolution, 91-day temporal resolution). SAR has also been used to map ice flow on Antarctica (Rignot et al. 2011).

Sea, lake, and river ice cover can be mapped using optical techniques (Jeffries et al. 2005), while thickness has been measured using ICESat and passive microwave sensors (e.g., Kwok and Rothrock 2009). The difference between first-year sea ice and older sea ice can be identified by changes in salinity using multichannel passive microwave sensors like the Advanced Microwave Scanning Radiometer for Earth Observing System (AMSR-E) onboard NASA's Aqua satellite (global spatial extent, $474 \mathrm{~km}$ spatial resolution, 12-hour temporal resolution, operational 2002-2015). River ice mapping is critical for monitoring and predicting river habitat quality and duration for a variety of organisms (e.g., Charney and Record 2016; Pavelsky and Zarnetske 2017). The extent and duration of river icing types have been mapped with different polarizations of passive microwave data from Canada's RADARSAT-1 (1995-2013) and RADARSAT-2 (launched 2007) (Weber et al. 2003; Jeffries et al. 2005; Yoshikawa et al. 2007 for aufeis features) and with MODIS Terra (Pavelsky and Zarnetske 2017). 


\subsection{Remote Sensing of Biodiversity}

Approaches for using RS to track biodiversity are reviewed in several chapters in this book (Fernandez and Pereira, Chap. 18; Serbin and Townsend, Chap. 4; Meireles et al., Chap. 7). Biodiversity has many forms-including taxonomic, functional, genetic, and phylogenetic diversity (Serbin and Townsend, Chap. 4; Meireles et al., Chap. 7). Each form may exhibit different relationships with both geophysical and biological drivers, owing to a variety of mechanisms (Gaston 2000; Lomolino et al. 2010). For example, reorganization of organisms in response to changing environments leads to species assemblages becoming more or less similar through biotic homogenization or differentiation (Baiser et al. 2012). Such biotic homogenization/ differentiation is usually characterized taxonomically (Olden and Rooney 2006). However, functional traits (i.e., traits representing the interface between species and their environment) possessed by species are often more important to ecosystem functions valued by society (Baiser and Lockwood 2011) and may be more appropriate to use in assessing biodiversity-ecosystem function relationships (Flynn et al. 2011). Many functional traits may also exhibit a phylogenetic signal (Srivastava et al. 2012), so it is important to consider multiple measures of diversity (i.e., taxonomic, functional, and phylogenetic) when assessing patterns of biodiversity (Serbin and Townsend, Chap. 4; Meireles et al., Chap. 7; Lausch et al. 2016; Lausch et al. 2018).

One caveat to measures of biodiversity generated from high-resolution RS data is that as the spatial resolution of data increases, the spatial extent typically decreases (Turner 2014; Gamon et al., Chap. 16). This limitation hinders our ability to understand how biodiversity relates to different drivers (e.g., geodiversity) at different spatial scales to better inform conservation decisions. There have been recent calls from scientists for new satellite missions and data integration efforts to address this issue (Schimel et al., Chap. 19). For instance, Jetz et al. (2016) call for a Global Biodiversity Observatory to generate worldwide remotely sensed data on several plant functional traits. Petorelli et al. (2016) and Fernández and Pereira (Chap. 18) identify satellite RS data that, given technological and algorithmic developments in the near future, could be capable of meeting the criteria of EBVs for conservation outlined by the international Group on Earth Observations-Biodiversity Observation Network (GEO BON) at a global spatial extent.

Until finer resolution, remotely sensed biodiversity data exist at large spatial extents, data available from in-situ measurements of organisms can inform the relationships between biodiversity and geodiversity. Publically available biodiversity data with geographic locations include expert range maps of individual species from IUCN (IUCN 2017), occurrence data [e.g., Global Biodiversity Information Facility (GBIF, GBIF 2016); Botanical Information and Ecology Network (BIEN, Enquist et al. 2016)], citizen science networks [e.g., Invasive Plant Atlas of New England, IPANE, Bois et al. 2011], and national [e.g., US Forest Service Forest Inventory and Analysis (FIA), Bechtold and Paterson 2005)] and international inventory networks [e.g., the Amazon Forest Inventory Network (RAINFOR), Peacock et al. 2007]. 
Each of these data sets comes with its own uncertainties (e.g., observation errors) and user challenges. For instance, citizen science data require detailed metadata on the sampling process to ensure that citizen scientists are able to reduce error and bias as they collect data and to enable those analyzing the data to model potential uncertainty (Bird et al. 2014). Despite these sources of uncertainty and logistical hurdles, these data provide a useful starting point for understanding the relationship between biodiversity and geodiversity.

\subsection{A Case Study Linking RS of Geodiversity to Tree Diversity in the Eastern United States}

To motivate explorations of the relationship between biodiversity and geodiversity with remotely sensed data, we provide an example using biodiversity data from the FIA program of the US Forest Service (O'Connell et al. 2017) and geodiversity data on elevation from SRTM. We selected elevation as a covariate because patterns of tree diversity often vary with elevation (Körner 2012). While some studies promote the use of many geodiversity components (Serrano et al. 2009; Hjort and Luoto 2010; Bailey et al. 2017; Tukiainen et al. 2017), a great deal of the variation in geodiversity is captured by the standard deviation in elevation (Hjort and Luoto 2012), which is used in this analysis.

The FIA program uses a two-phase protocol to characterize the nation's forest resources. In phase one, all land in the United States is categorized as either "forested" or "not forested" using remotely sensed data. In phase two, in every 2428 ha of land classified as forested, one permanent FIA plot is placed for in-situ sampling. Each FIA plot consists of four 7.2-m-fixed-radius subplots wherein all trees $>12.7 \mathrm{~cm}$ diameter at breast height are measured. FIA plot measurements began in the 1940s, but a consistent nationwide sampling protocol was not implemented until 2001. In the analysis presented, we used data from the most recent full plot FIA inventory from 2012-2016; the SRTM data were collected in 2009. Although there is not perfect temporal overlap in the geodiversity and biodiversity data used in this example, we do not expect that topography at a spatial resolution of $50 \mathrm{~km}$ would have changed much over the time period encompassed by both data sets for this part of the world.

We fixed the spatial extent of the analysis to the contiguous United States east of $100^{\circ} \mathrm{W}$ longitude $(\mathrm{n}=90,250$ plots total) and selected a grain size of $50 \mathrm{~km}$ for calculating alpha (within site), beta (turnover between sites), and gamma (total across all sites) diversities within a radius centered on each FIA plot. All biodiversity metrics were based on species abundances as quantified by the total basal area of each tree species in each plot. Alpha diversity was calculated as the median abundance-weighted effective species number of all plots falling within a $50 \mathrm{~km}$ radius of the focal FIA plot, including the focal plot. Beta diversity was calculated as the mean abundance-weighted pairwise Sørensen dissimilarity of all pairs of plots within a $50 \mathrm{~km}$ radius of the focal plot, including the focal plot. Gamma 
A)Alpha-diversity

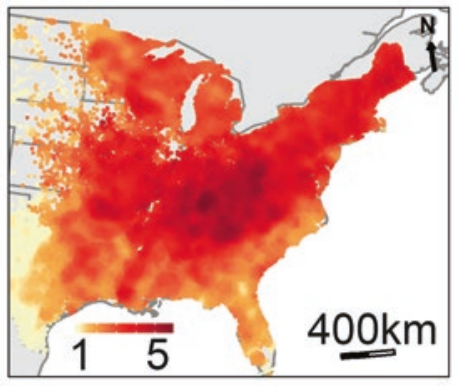

C) Gamma-diversity

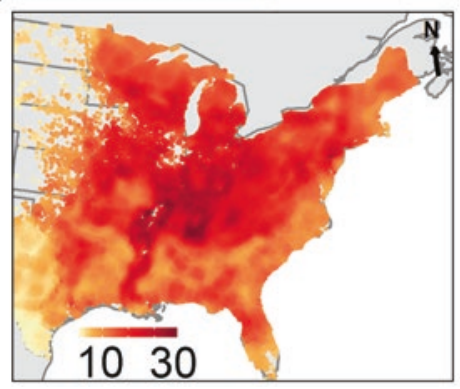

B) Beta-diversity

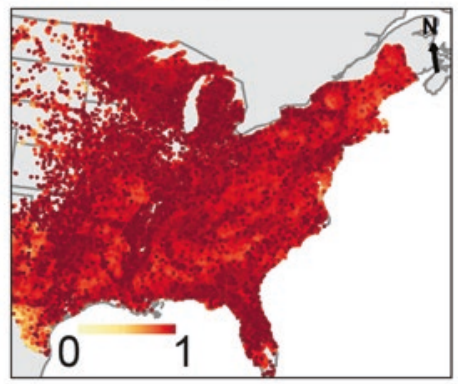

D)Elevation variability

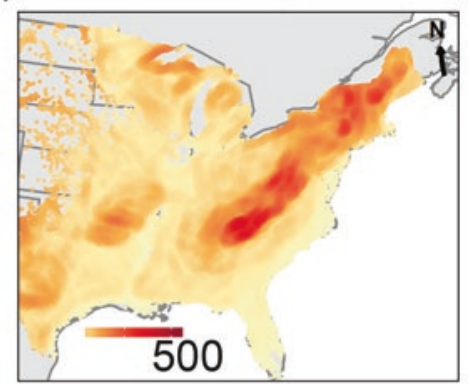

Fig. 10.3 Mapped variation in tree diversity calculated within $50 \mathrm{~km}$ radii. Tree data come from the Forest Inventory and Analysis of the US Forest Service (FIA, O'Connell et al. 2017. (a) Taxonomic alpha diversity. (b) Taxonomic beta diversity. (c) Taxonomic gamma diversity. (d) The standard deviation of all elevation pixels within the radius from 30 m Shuttle Radar Topography Mission (SRTM) data

diversity was calculated as the aggregated effective species number of all plots within a $50 \mathrm{~km}$ radius of the focal plot, including the focal plot. For each $50 \mathrm{~km}$ radius centered on a focal plot, we computed the standard deviation of elevation across pixels within the radius from $30 \mathrm{~m}$ SRTM data (Fig. 10.3). To avoid edge effects, all plots within $100 \mathrm{~km}$ of the political borders of the United States were excluded, retaining 80,411 plots. To avoid pseudo-replication, we generated 999 subsamples of plots separated by at least $100 \mathrm{~km}$, yielding $~ 370$ plots per subsample. Because of the saturating relationship between biodiversity and geodiversity, we fit natural splines with 3 degrees of freedom to relate all focal plots' univariate diversity to elevation standard deviation (SD) (linear regression for alpha and gamma diversity; beta regression for beta diversity), and goodness of fits of the models were assessed with r-squared (Fig. 10.4).

This example shows how the relationships between biodiversity and geodiversity for a subset of different biodiversity metrics vary depending on the metric of biodiversity calculated. Here beta and gamma diversity do not show a strong relationship $\left(r^{2}=0.03\right.$ and $r^{2}=0.07$, respectively; Figs. 10.3 and 10.4) with geodiversity, but alpha diversity shows a stronger, positive relationship with elevation variability 

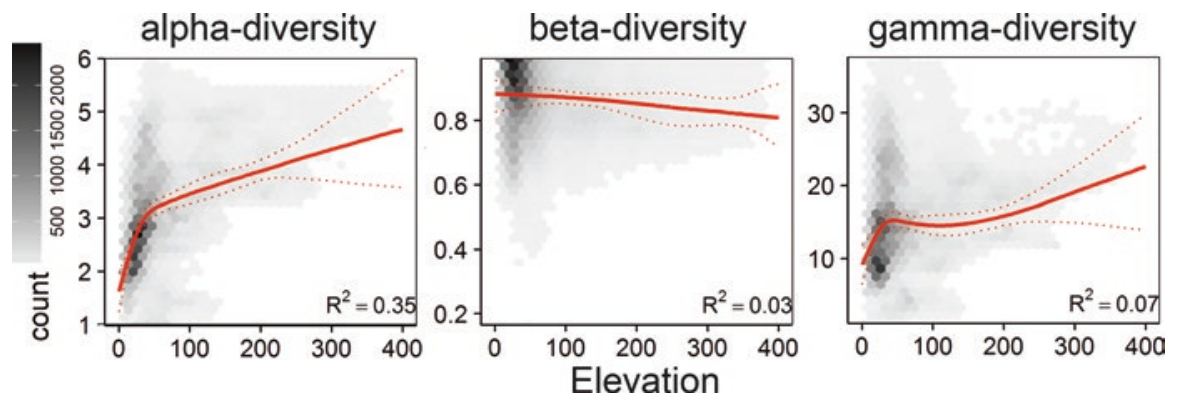

Fig. 10.4 The relationships between three measures of tree taxonomic diversity (alpha, beta, and gamma) and geodiversity (i.e., elevation standard deviation) at a spatial resolution of $50 \mathrm{~km}$. Points indicate the aggregated plots, and the red line indicates the natural spline relationship fitted with a linear regression model for alpha and gamma diversity and a beta regression model for beta diversity. Dotted lines represent the $2.5 \%$ and $97.5 \%$ quantiles of predicted values across 999 spatially stratified random subsamples of the data, and the given r-squared value is the mean across all the subsamples

$\left(r^{2}=0.35\right.$; Figs. 10.3 and 10.4). Interestingly, in a sister study, Zarnetske et al. (2019) found that FIA tree diversity with a different spatial extent-in California, Washington, and Oregon — showed a different relationship with elevation variability. Furthermore, beta and gamma diversity showed a strong increasing relationship with elevation variability, whereas alpha diversity did not. This comparison between the case study illustrated in this chapter and the results of Zarnetske et al. (2019) highlights the importance of considering how the relationship between geodiversity and biodiversity may change with different spatial scales (Gamon et al., Chap. 16). Bailey et al. (2017) also showed that landforms detected with airborne RS at smaller spatial resolutions explained more of the variation in alpha diversity of alien vascular plants in Great Britain than did climate measured at larger spatial resolutions. While these examples do not provide an exhaustive exploration of the ways in which tree diversity responds to geodiversity, they clearly show how remotely sensed data may help us understand the relationships between geodiversity and biodiversity and how these relationships may be different in different geographic areas.

This example shows how the relationship between taxonomic biodiversity and geodiversity depends on the biodiversity metric chosen. There are various methodologies for calculating biodiversity metrics and various facets of biodiversity (e.g., functional, taxonomic, phylogenetic), and the theoretical pros and cons of each remain controversial (e.g., Jost 2007; Clark 2016), so it may not be obvious which metric is the best. Furthermore, different conclusions may be drawn depending on the types of taxa used in the analysis.

In a similar vein, the choice of an appropriate geodiversity metric may not be obvious. Here we use a single measure of geodiversity, standard deviation of elevation. However, different definitions of the term geodiversity include different components of geology, topography, and, in some instances, climate (Parks and Mulligan 2010; Gray 2013). The amalgamation of these different variables to characterize geodiversity as a whole is an area in need of development. 


\subsubsection{Challenges and Opportunities}

\subsubsection{The Interplay Between Biodiversity and Geodiversity over Time}

Although we have focused thus far on the effects of geodiversity on biodiversity, biodiversity can also affect geodiversity. Ecosystem engineers (Jones et al. 1994) and foundation species (Record et al. 2018) can influence biodiversity through habitat formation (Hastings et al. 2007). Geodiversity can be modified by species impacting the structure and function of landscape features. For example, elephants dig, form trails, and trample (Haynes 2012), and vegetation and sediment interact to form streams and coastal dunes (Zarnetske et al. 2012; Atkinson et al. 2017). In turn, these species-modified features can feed back to mediate the strength and direction of biotic interactions among species and ultimately influence patterns of biodiversity (Zarnetske et al. 2017). Even climate can be influenced by biodiversity and biogeographic patterns. Forests directly affect Earth's climate through atmospheric exchange (Bonan 2008). If shrubs expand by $20 \%$ and continue to dominate in areas north of $60^{\circ} \mathrm{N}$ latitude, for example, Arctic annual temperature could increase by $0.66^{\circ} \mathrm{C}-1.84^{\circ} \mathrm{C}$, via decreased albedo and increased evapotranspiration (Bonfills et al. 2012).

Many of these feedbacks between biodiversity and geodiversity are not detectable given a single snapshot in time and require longer time series. RS with repeat samples taken as satellites orbit the Earth provide data with high spatial and deep temporal coverage that can be used to assess changes in the dominance of a species within a community (Pau and Dee 2016). Changes in the dominance structure of communities (or its counterpart, evenness) should be early indicators of global change because these changes occur before the complete loss or replacement of species (Hillebrand et al. 2008). Furthermore, tracking dominant species should be especially important for quantifying biomass or abundance-driven ecosystem functions and services (Pau and Dee 2016). For instance, Cavanaugh et al. (2013) used 28 years of Landsat imagery to map the poleward expansion of mangroves, which are important in preventing coastal erosion, in the eastern United States. Furthermore, the 45-year time series of Landsat data provide an excellent opportunity for detecting changes in habitat due to species, which may have extreme impacts on the abiotic stage.

\subsubsection{Scale and Expertise Mismatches}

The relationships between geodiversity and biodiversity are likely to change across spatial and temporal scales. For instance, a focused spotlight shining down on one part of the stage (e.g., the tip of a mountaintop) might exhibit different covariation between geodiversity and biodiversity than a broad swath of light on another portion of the stage (e.g., an expansive low-lying valley). Spatial patterns of biodiversity and geodiversity are each scale dependent (Rahbek 2005; Bailey et al. 2017; Cavender-Bares et al., Chap. 2; Gamon et al., Chap. 16), and it is well established 
that ecological processes influencing the assembly of communities of organisms are scale dependent (Levin 1992; McGill 2010). A spatially explicit framework for conceptualizing community assembly describes external filters (e.g., climate or soils) that sort species from a regional pool at a spatial scale larger than the community and internal filters that sort species into a community from a subset of the species that make it through the external filter (e.g., microenvironmental heterogeneity, biotic interactions; Violle et al. 2012; Fig. 10.5). These "assembly rules" about how communities form remain a controversial paradigm with uncertainty about which processes operate at which scales (McGill 2010; Belmaker et al. 2015). Observing and quantifying relationships between geodiversity and biodiversity and how these relationships change with scale, however, are essential for moving forward regardless of one's position on these controversies. To most effectively use geodiversity to help explain and predict patterns of biodiversity, we need a framework that addresses the scaling relationship between biodiversity and geodiversity.

Furthermore, there are important disconnects in both scale and expertise between biodiversity science and RS (Petorelli et al. 2014) that once addressed will aid in the development of such a framework. Whereas the availability of remotely sensed geodiversity data products has increased, many of the scales are too coarse to reflect the environmental and biological conditions that often drive more fine-scaled spatially heterogeneous biodiversity patterns (Nadeau et al. 2017) and thus may require complex post-processing techniques unfamiliar to most biodiversity scientists before they can be used appropriately in biodiversity models. Also, there are likely many important aspects of geodiversity that at this time can only be derived through in-situ measurements and cannot be remotely sensed. Determining how physical and biological drivers influence biodiversity across spatial and temporal scales is a central focus of ecology. However, most models predicting future patterns of biodiversity assume broad-scale climatic drivers-temperature and precipitation-are sole drivers and leave out important biological drivers (Zarnetske et al. 2012; Record et al. 2013). Biological drivers such as dispersal ability and biotic interactions (e.g., competition) are often mediated by the structure of the landscape, including geophysical feature configuration, topographic complexity, and habitat patch arrangement (Zarnetske et al. 2017). Yet a significant knowledge gap remains about how the relationships between biodiversity and its geophysical and biological drivers change with respect to space and time- - perhaps owing to the scale mismatch between finescale point-level biodiversity data and many coarse-scale remotely sensed data products.

Many ecological questions are addressed at scales much finer than the grain size of MODIS or GPM, which makes statistical downscaling a necessity for remotely sensed products to be used. Yet the landscape of options for statistical downscaling is vast and complex (Pourmokhtarian et al. 2016). In addition, the increasing availability of airborne topographic data like LiDAR makes the possibility of finer-grain analysis even more viable, yet these data also bring another dimension of complexity and a lack of standardization across platforms and methods.

Open access analytical tools and training will provide ways forward given data downloading and processing challenges. The Application for Extracting and 


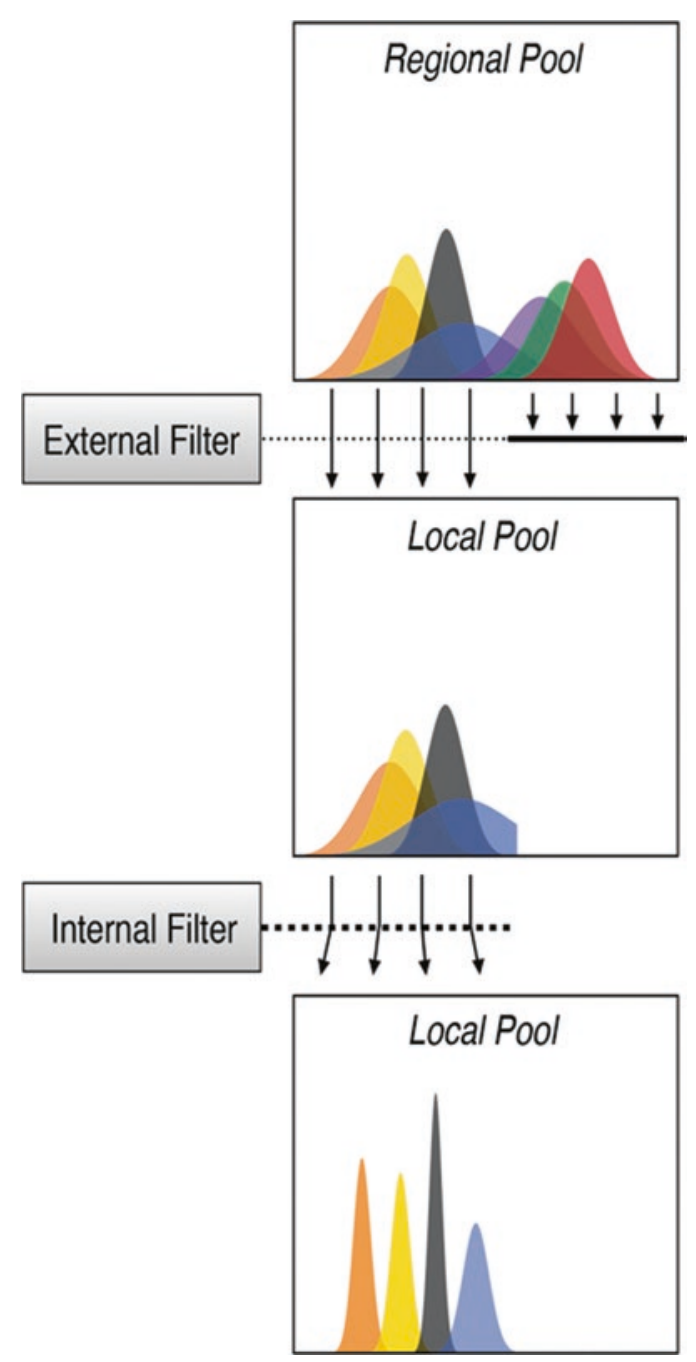

Fig. 10.5 Conceptual diagram adapted from Violle et al. (2012) showing how spatially explicit (i.e., local versus regional) filters influence the assembly of traits in an observed community (bottom schematic). The regional species pool (top schematic) contains all of the species capable of seeding into the local community. However, the observed local community may only contain a subset of the species in the regional pool after species have passed through a series of filters. Both internal and external filters encompass different aspects of the stage, whereas internal filters may also include the actors. Examples of external filters include broad-scale climate or soil types for which some species may not have physiological tolerances. Internal filters include microenvironmental heterogeneity and/or biotic interactions. In this schematic, the traits that passed through the external and internal filters partition in the observed local community, perhaps due to competitive effects between species for resources 
Exploring Analysis Ready Samples (AppEEARS) offered by NASA and US Geological Survey (USGS) is a user-friendly tool that enables simple and efficient downloads and transformations of geospatial data from a number of federal data archives from the United States [e.g., the Land Process Distributed Active Archive Center (LP DAAC)]. Additionally, Geomorphons provides a user-friendly interface that automates the calculation of complex geodiversity features from topography data (Jasiewicz and Stepinski 2013). Training the next generation of ecologists and conservation biologists in RS will be integral to overcoming some of these hurdles and bridging the gaps between RS and ecology and conservation.

\subsection{Conclusion}

Cross-scale studies of relationships between geodiversity and biodiversity using RS and large field-based data sets hold promise for evaluating processes underlying biodiversity and identifying scales and methods for its monitoring and management. Realizing this potential will require more interaction among biodiversity scientists, geoscientists, RS experts, and statisticians to reconcile the challenges associated with differences in scales, available data products, disciplinary barriers, and available methods for connecting geodiversity to biodiversity. These challenges are far from trivial, but overcoming them has the potential to result in key ecological insights that will help us to be better stewards of the entire ecological theater.

Acknowledgments We thank J. Cavender-Bares, J. Gamon, A. Lausch, M. Madritch, F. Schrodt, P. Townsend, and S. Ustin for comments on the chapter while at NIMBioS. Funding for the NASA bioXgeo working group was provided by the National Aeronautics and Space Administration (NASA)EcologicalForecasting Program,EarthScienceDivision, Grant\#NNX16AQ44G. Additional support for PLZ, KD, QR, JG, and AF came from Michigan State University. SR was supported by Bryn Mawr College KG Fund. AMW acknowledges support from NASA's Ecological Forecasting Program, Earth Science Division, Grant \#NNX16AQ45G. MH was supported by the NASA Biodiversity Program and MODIS Science Program, Grant \#NNX14AP07G. SO acknowledges support from the NSF Macrosystems Biology Program, Grant \#638688. We thank the National Center for Ecological Analysis and Synthesis (NCEAS) for housing the working group meetings. KDG was supported by an AAAS Science and Technology Policy Fellowship served at NASA. The views expressed in this paper do not necessarily reflect those of NASA, the US Government, or the American Association for the Advancement of Science.

\section{References}

Alcântara EH, Stech JL, Lorenzzetti JA, Bonnet MP, Casamitjana X, Assireu AT, de Moraes L, Novo EM (2010) Remote sensing of water surface temperature and heat flux over a tropical hydroelectric reservoir. Remote Sens Environ 114:2651-2665

Anderson MG, Ferree CE (2010) Conserving the stage: climate change and the geophysical underpinnings of species diversity. PLoS One 5:e11554 
Atkinson CL, Allen DG, Davis L, Nickerson ZL (2017) Incorporating ecogeomorphic feedbacks to better understand resiliency in streams: a review and directions forward. Geomorphology 305:123-140

Baiser B, Lockwood JL (2011) The relationship between functional and taxonomic homogenization. Glob Ecol Biogeogr 20:134-144

Baiser B, Olden JD, Record S, Lockwood JL, McKinney ML (2012) Pattern and process of biotic homogenization in the New Pangaea. P R Soc B 279:4772-4777

Barton PS, Cunningham SA, Manning AD, Gibb H, Lindenmayer DB, Didham RK (2013) The spatial scaling of beta diversity. Glob Ecol Biogeogr 22:639-647

Bechtold WA, Paterson PL (eds) (2005) The enhanced forest inventory and analysis program: national sampling design and estimation procedure. General technical report SRS-80. USA Department of Agriculture, Forest Service Southern Research Station, Asheville, NC, USA

Beier P, Brost B (2010) Use of land facets to plan for climate change: conserving the arenas, not the actors. Cons Biol 24:701-710

Beier P, Hunter ML, Anderson M (2015) Special section: conserving nature's stage. Cons Biol 29:613-617

Belmaker J, Zarnetske P, Tuanmu M-N, Zonneveld S, Record S, Strecker A, Beaudrot L (2015) Empirical evidence for the scale dependence of biotic interactions. Glob Ecol Biogeogr 24:750-761

Benito-Calvo A, Pérez-González A, Magri O, Meza P (2009) Assessing regional geodiversity: the Iberian Peninsula. Earth Surf Proc Land 34:1433-1445

Bird TJ, Bates AE, Lefcheck JS, Hill NA, Thomson RJ, Edgar GJ, Stuart-Smith RD, Wotherspoon S, Krkosek M, Stuart-Smith JF, Pecl GT (2014) Statistical solutions for error and bias in global citizen science datasets. Biol Conserv 173:144-154

Bois ST, Silander JA, Mehrhoff LJ (2011) Invasive plant atlas of New England: the role of citizens in the science of invasive alien species detection. Bioscience 61:763-770

Bonan GB (2008) Forests and climate change: forcings, feedbacks, and the climate benefits of forests. Science 320:1444-1449

Bonfills CJW, Phillips TJ, Lawrence DM, Cameron-Smith P, Riley WJ, Subin ZM (2012) On the influence of shrub height and expansion on northern high latitude climate. Environ Res Lett 7:015503

Burakowski EA, Ollinger SV, Lepine LC, Schaaf CB, Wang Z, Dibb JE, Hollinger DY, Kim J, Erb A, Martin ME (2015) Spatial scaling of reflectance and surface albedo over a mixed-use, temperate forest landscape during snow-covered periods. Remote Sens Environ 158:465-477

Campbell S, Affleck RT, Sinclair S (2018) Ground-penetrating radar studies of permafrost, periglacial, and near-surface geology at McMurdo Station, Antarctica. Cold Reg Sci Technol 148:38-49

Cao C, Xiong S, Wu A, Wu X (2008) Assessing the consistency of AVHRR and MODIS L1B reflectance for generating fundamental climate data records. J Geophys Res-Atmos 113:1-10

Catapano I, Antonio Affinito, Gianluca Gennarelli, Francesco di Maio, Antonio Loperte, Francesco Soldovieri, (2014) Full three-dimensional imaging via ground penetrating radar: assessment in controlled conditions and on field for archaeological prospecting. Applied Physics A 115 (4):1415-1422

Cavanaugh KC, Kellner JR, Forde AJ, Gruner DS, Parker JD, Rodriguez W, Feller IC (2013) Poleward expansion of mangroves is a threshold response to decreased frequency of extreme cold events. P Natl Acad Sci USA 111:723-727

Chadwick OA, Derry LA, Vitousek PM, Huebert BJ, Hedin LO (1999) Changing sources of nutrients during four million years of ecosystem development. Nature 397:491-497

Chapin FS, Walker BH, Hobbs RJ, Hooper DU, Lawton JH, Sala OE, Tilman D (1997) Biotic control over the functioning of ecosystems. Science 277:500-504

Charney ND, Record S (2016) Combining incidence and demographic modelling approaches to evaluate metapopulation parameters for an endangered riparian plant. AOB Plants 8:1-11

Charney ND, Babst F, Poulter B, Record S, Trouet VM, Frank D, Enquist BJ, Evans MEK (2016) Observed forest sensitivity to climate implies large changes in 21st century North American forest growth. Ecol Lett 19:1119-1128 
Clark JS (2016) Why species tell more about traits than traits about species: predictive analysis. Ecology 97:1979-1993

Corbley K (2010) GEOSAR-making mapping the 'impossible' possible. GEO Inf 13:43-47

Cord A, Rödder D (2011) Inclusion of habitat availability in species distribution models through multi-temporal remote sensing data? Ecol Appl 21:3285-3298

Cowling RM, Proches S, Partridge TC (2009) Explaining the uniqueness of the Cape flora: incorporating geomorphic evolution as a factory for explaining its diversification. Mol Phylogenet Evol 51:64-74

Crowley JK (1993) Mapping playa evaporite minerals with AVIRIS data: a first report from Death Valley, California. Remote Sens Environ 44:337-356

Cudahy TJ, Hewson R, Huntington JF, Quigley MA, Barry PS (2001) The performance of the satellite-borne Hyperion hyperspectral VNIR-SWIR imaging system for mineral mapping at Mount Fitton, South Australia. In: Geoscience and remote sensing symposium (IGARSS 2001), pp 314-316

Davis JL, Annan AP (1989) Ground-penetrating radar for high-resolution mapping of soil and rock stratigraphy. Geophys Prospect 37:531-551

Deblauwe V, Droissart V, Bose R, Sonké B, Blach-Overgaard A, Svenning JC, Wieringa JJ, Ramesh BR, Stévart T, Couvreur TLP (2016) Remotely sensed temperature and precipitation data improve species distribution modelling in the tropics. Glob Ecol Biogeogr 25:443-454

Dietz AJ, Kuenzer C, Gessner U (2011) Remote sensing of snow-a review of available methods. Int J Remote Sens 33:4049-4134

Dufour A, Gadallah F, Wagner HH, Guisan A, Buttler A (2006) Plant species richness and environmental heterogeneity in a mountain landscape: effects of variability and spatial configuration. Ecography 29:573-584

Elith J, Leathwick JR (2009) Species distribution models: ecological explanation and prediction across space and time. Ann Rev Ecol Evol Syst 40:677-697

Engelbrecht BMJ, Comita LS, Condit R, Kursar TA, Tyree MT, Turner BL, Hubbell SP (2007) Drought sensitivity shapes species distribution patterns in tropical forests. Nature 447:80-83

Enquist BJ, Condit R, Peet RK, Schildhauer M, Thiers BM (2016) Cyberinfrastructure for an integrated botanical information network to investigate the ecological impacts of global climate change on plant biodiversity. Peer J 4:e2615v2

Entekhabi D, Yueh S, O’Neill PE, Kellogg KH, Allen A, Bindlish R, Brown M, Chan S, Colliander A, Crow WT (2014) SMAP handbook: soil moisture active passive

ESA. Endangered Species Act 197316 U.S.C. § 1531 et seq.

Evans MEK, Merow C, Record S, McMahon SM, Enquist BJ (2016) Towards process-based range modeling of many species. Trends Ecol Evol 31:860-871

Ferrier S, Manion G, Elith J, Richardson K (2007) Using generalized dissimilarity modelling to analyse and predict patterns of beta diversity in regional biodiversity assessment. Div Dist 13:252-264

Fick SE, Hijmans RJ (2017) WorldClim 2: new 1-km spatial resolution climate surfaces for global land areas. Int J Climatol 37:4302-4315

Flynn DFB, Mirotchnick N, Jain M, Palmer MI, Naeem S (2011) Functional and phylogenetic diversity as predictors of biodiversity-ecosystem function relationships. Ecology 92:1573-1581

Funk CP, Peterson P, Landsfeld M, Pedreros D, Verdin J, Shukla S, Husak G, Rowland J, Harrison L, Hoell A, Michaelsen J (2015) The climate hazards infrared precipitation with stations - a new environmental record for monitoring extremes. Sci Data 2:150066

Gaston KJ (2000) Global patterns in biodiversity. Nature 405:220-227

GBIF (2016) Global biodiversity information facility. Available at: https://gbif.org

Giardino C, Brando VE, Gege P, Pinnel N, Hochberg E, Knaeps E, Reusen I, Doerffer R, Bresciani M, Braga F, Foerster S, Champollion N, Dekker A (2018) Imaging spectrometry of inland and coastal waters: state of the art, achievements and perspectives. Surv Geophys 40:1-29

Ginoux P, Prospero JM, Gill TE, Hsu NC, Zhao M (2012) Global-scale attribution of anthropogenic and natural dust sources and their emission rates based on Modis deep blue aerosol products. Rev Geophys 50:1-36 
Goetz AFH, Vane G, Solomon JE, Rock BN (1985) Imaging spectrometry for earth remote sensing. Science 228:1147-1153

Gray M (2008) Geoheritage 1. Geodiversity: a new paradigm for valuing and conserving geoheritage. Geosci Can 35:2

Gray M (2013) Geodiversity: valuing and conserving abiotic nature, 2nd edn. Wiley-Blackwell, London

Green RO, Eastwood ML, Sarture CM, Chrien TG, Aronsson M, Chippendale BJ, Faust JA, Pavri BE, Chovit CJ, Solis M, Olah MR (1998) Imaging spectroscopy and the airborne visible/infrared imaging spectrometer (AVIRIS). Remote Sens Environ 65:227-248

Grunwald S, Thompson JA, Boettinger JL (2011) Digital soil mapping and modeling at continental scales: finding solutions for global issues. Soil Sci Soc Am J 75:1201

Gupta RP (2013) Remote sensing geology, 2nd edn. Springer, New York

Hastings A, Byers JE, Crooks JA, Cuddington K, Jones CG, Lambrinos JG, Talley TS, Wilson WG (2007) Ecosystem engineering in space and time. Ecol Lett 10:153-164

Haynes G (2012) Elephants (and extinct relatives) as earth-movers and ecosystem engineers. Geomorphology 157:99-107

Hengl T, De Jesus JM, MacMillan RA, Batjes NH, Heuvelink GBM, Ribeiro E, Samuel-Rosa A, Kempen B, Leenaars JGB, Walsh MG, Gonzalez MR (2014) SoilGrids1km - global soil information based on automated mapping. PLoS One 9:e105992

Hestir EL, Brando VE, Bresciani M, Giardino C, Matta E, Villa P, Dekker AG (2015) Measuring freshwater aquatic ecosystems: the need for a hyperspectral global mapping satellite mission. Remote Sens Environ 167:181-195

Hewson RD, Cudahy TJ, Mizuhiko S, Ueda K, Mauger AJ (2005) Seamless geological map generation using ASTER in the Broken Hill-Curnamona Province of Australia. Remote Sens Environ 99:159-172

Hijmans RJ, Cameron SE, Parra JL, Jones PG, Jarvis A (2005) Very high resolution interpolated climate surfaces for global land areas. Int J Climatol 25:1965-1978

Hijmans R, van Etten J (2019) raster: Geographic data analysis and modeling. R Package version $3.0-7$

Hillebrand H, Bennet DM, Cadotte M (2008) Consequences of dominance: a review of evenness effects on local and regional ecosystem processes. Ecology 89:1510-1520

Hjort J, Luoto M (2010) Geodiversity of high-latitude landscapes in northern Finland. Geomorphology 115:109-116

Hjort J, Luoto M (2012) Can geodiversity be predicted from space? Geomorphology 153:74-80

Hjort J, Heikkinen RK, Luoto M (2012) Inclusion of explicit measures of geodiversity improve biodiversity models in a boreal landscape. Biodivers Conserv 21:3487-3506

Hutchinson GE (1965) The ecological theater and the evolutionary play. Yale University Press, Connecticut

International Union for Conservation of Nature and Natural Resources (2001) IUCN red list categories and criteria (Int. Union Conserv. Nat. Nat. Resour. Species Survival Commission, Cambridge, U.K.) Version 3.1

IUCN (2017) The IUCN red list of threatened species. Version 2017-2. Available at: http://www. iucnredlist.org

Jackova K, Romportl D (2008) The relationship between geodiversity and habitat richness in Sumava National Park and Krivoklatsko PLA (Czech Republic): a qualitative analysis approach. J Landsc Ecol 1:23-28

Janzen DH (1967) Why mountain passes are higher in the tropics. Am Nat 101:233-249

Jasiewicz J, Stepinski TF (2013) Geomorphons-a pattern recognition approach to classification and mapping of landforms. Geomorphology 182:147-156

Jeffries MO, Morris K, Kozlenko N (2005) Ice characteristics and processes, and remote sensing of frozen rivers and lakes. In: Duguay CR, Pietroniro A (eds) Remote sensing in northern hydrology: measuring environmental change. American Geophysical Union, Washington D.C., pp 63-90 
Jenny H (1941) Factors of soil formation. McGraw-Hill, New York

Jetz W, Cavender-Bares J, Pavlick R, Schimel D, Davis FW, Asner GP, Guralnick R, Kattge J, Latimer AM, Moorcroft P, Scaepman ME, Schildhauer MP, Schneider FD, Schrodt F, Stahl U, Ustin SL (2016) Monitoring plant functional diversity from space. Nat Plants 2:e3

John W. Williams, Stephen T. Jackson, (2007) Novel climates, no-analog communities, and ecological surprises. Frontiers in Ecology and the Environment 5 (9):475-482

Jones CG, Lawton JH, Shachak M (1994) Organisms as ecosystem engineers. In: Samson FB, Knopf FL (eds) Ecosystem management. Springer, New York, pp 130-147

Joseph J. Bailey, Doreen S. Boyd, Jan Hjort, Chris P. Lavers, Richard Field, (2017) Modelling native and alien vascular plant species richness: At which scales is geodiversity most relevant? Global Ecology and Biogeography 26(7):763-776

Jost L (2007) Partitioning diversity into independent alpha and beta components. Ecology 88:2427-2439

Kampe TU, Johnson BR, Kuester M, Keller M (2010) NEON: the first continental-scale ecological observatory with airborne remote sensing of vegetation canopy biochemistry and structure. $\mathrm{J}$ Appl Remote Sens 4:043510

Kerr JT, Packer L (1997) Habitat heterogeneity as a determinant of mammal species richness in high-energy regions. Nature 385:252-254

Körner C (2012) Alpine treelines: functional ecology of the global high elevation tree limits. Springer, New York, pp 21-30

Kozlowski S (1999) Programme of geodiversity conservation in Poland. Pol Geol Inst Spec Papers 2:15-19

Krause FA, Lefkoff AB, Dietz JB (1993) Expert system-based mineral mapping in northern Death Valley, California/Nevada, using the airborne visible/infrared imaging spectrometer (AVIRIS). Remote Sens Environ 44:309-336

Kwok R, Rothrock DA (2009) Decline in Arctic Sea ice thickness from submarine and ICESat records. Geophys Res Lett 36:1958-2008

Lacoul P, Freedman B (2006) Environmental influences on aquatic plants in freshwater ecosystems. Environ Rev 14:89-136

Lausch A, Bannehr L, Beckmann M, Boehm C, Feilhauer H, Hacker JM, Heurich M, Jung A, Klenke R, Neumann C, Pause M, Rocchini D, Schaepman ME, Schmidtlein S, Schulz K, Selsam P, Settele J, Skidmore AK, Cord AF (2016) Linking earth observation and taxonomic, structural, and functional biodiversity: local to ecosystem perspectives. Ecol Indic 70:317-339

Lausch A, Borg E, Bumberger J, Dietrich P, Heurich M, Huth A, Jung A, Klenke R, Knapp S, Mollenhauer H, Paasche H, Paulheim H, Pause M, Schweitzer C, Schmulius C, Settele J, Skidmore A, Wegmann M, Zacharias S, Kirsten T, Schapeman M (2018) Understanding forest health with remote sensing, part III: requirements for a scalable multi-source forest health monitoring network based on data science approaches. Remote Sens 10:1120

Lawler JJ, Ackerly DD, Albano CM, Anderson MG, Dobrowski SZ, Gill JL, Heller NE, Pressey RL, Leidner AK, Böhm M, He KS, Nagendra H, Dubois G, Fatoyinbo T, Hansen MC, Paganini M, de Klerk HM, Asner GP, Kerr JT, Estes AB, Schmeller DS, Heiden U, Rocchini D, Pereira HM, Turak E, Fernandez N, Lausch A, Cho MA, Alcaraz-Segura D, McGeoch MA, Turner W, Mueller A, St-Louis V, Penner J, Petteri V, Belward A, Reyers B, Geller GN (2016) Framing the concept of satellite remote sensing essential biodiversity variables: challenges and future directions. Remote Sens Ecol Cons 2:122-131

Legendre P, Borcard D, Peres-Neto PR (2005) Analyzing beta diversity: partitioning the spatial variation of community composition data. Ecol Monogr 75:435-450

Levin SA (1992) The problem of pattern and scale in ecology. Ecology 73:1943-1967

Linlin Ge, Alex Hay-Man Ng, Xiaojing Li, Hasanuddin Z. Abidin, Irwan Gumilar, (2014) Land subsidence characteristics of Bandung Basin as revealed by ENVISAT ASAR and ALOS PALSAR interferometry. Remote Sensing of Environment 154:46-60

Lomolino MV, Brown JH, Sax DF (2010) Reticulations and reintegration of "A biogeography of the species" in Island Biogeography Theory Eds. Losos JB, Ricklefs RE. Princeton University Press, Princeton, NJ 
Marcott KC, Shakun JD, Clark PU, Mix AC (2013) A reconstruction of regional and global temperature for the past 11,300 years. Science 339:1198-1201

Massironi M, Bertoldi L, Calafa P, Visona D, Bistacchi A, Giardino C, Schiavo A (2008) Interpretation and processing of ASTER data for geological mapping and granitoids detection in the Saghro massif (eastern anti-atlas, Morocco). Geosphere 4:736-759

McGill BJ (2010) Matters of scale. Science 328:575-576

Moore I. D., R. B. Grayson, A. R. Ladson, (1991) Digital terrain modelling: A review of hydrological, geomorphological, and biological applications. Hydrological Processes 5(1):3-30

Mouillot D, Graham NAJ, Villéger S, Mason NWH, Bellwood DR (2013) A functional approach reveals community responses to disturbances. Trends Ecol Evol 28:167-177

Muller-Karger FE, Hestir E, Ade C, Turpie K, Roberts DA, Siegel D, Miller RJ, Humm D, Izenberg N, Morgan F et al (2018) Satellite sensor requirements for monitoring essential biodiversity variables of coastal ecosystems. Ecol Appl 28:749-760

Nadeau CP, Urban M, Bridle JR (2017) Coarse climate change projections for species living in a fine-scaled world. Glob Change Biol 23:12-24

Nathalie Pettorelli, Martin Wegmann, Andrew Skidmore, Sander Mücher, Terence P. Dawson, Miguel Fernandez, Richard Lucas, Michael E. Schaepman, Tiejun Wang, Brian O’Connor, Robert H.G. Jongman, Pieter Kempeneers, Ruth Sonnenschein, Allison K. Leidner, Monika Böhm, Kate S. He, Harini Nagendra, Grégoire Dubois, Temilola Fatoyinbo, Matthew C. Hansen, Marc Paganini, Helen M. de Klerk, Gregory P. Asner, Jeremy T. Kerr, Anna B. Estes, Dirk S. Schmeller, Uta Heiden, Duccio Rocchini, Henrique M. Pereira, Eren Turak, Nestor Fernandez, Angela Lausch, Moses A. Cho, Domingo Alcaraz-Segura, Mélodie A. McGeoch, Woody Turner, Andreas Mueller, Véronique St-Louis, Johannes Penner, Petteri Vihervaara, Alan Belward, Belinda Reyers, Gary N. Geller, Doreen Boyd, (2016) Framing the concept of satellite remote sensing essential biodiversity variables: challenges and future directions. Remote Sensing in Ecology and Conservation 2(3):122-131

NRC. National Research Council (2001) Basic research opportunities in earth science, pp 14-15 The National Academies Press, Washington, DC, USA. https://doi.org/10.17226/9981

O'Connell BM, Conkling BL, Wilson AM, Burrill EA, Turner JA, Pugh SA, Christensen G, Ridley $\mathrm{T}$, Menlove J (2017) The forest inventory and analysis database: database description and user's manual version 7.0 for phase 2. U.S. Department of Agriculture, Forest Service, p 830, Washington, DC, USA

Okin GS, Mahowald N, Chadwick OA, Artaxo P (2004) Impact of desert dust on the biogeochemistry of phosphorus in terrestrial ecosystems. Global Biogeochem Cy 18:2

Olden JD, Rooney TP (2006) On defining and quantifying biotic homogenization. Glob Ecol Biogeogr 15:113-120

Ollinger SV, Aber JD, Federer CA, Lovett GM, Ellis J (1995) Modeling physical and chemical climatic variables across the northeastern U.S. for a geographic information system. USDA Forest Service General Technical Report NE-191

Ollinger SV, Smith ML, Martin ME, Hallett RA, Goodale CL, Aber JD (2002) Regional variation in foliar chemistry and soil nitrogen status among forests of diverse history and composition. Ecology 83:339-355

Parks KE, Mulligan M (2010) On the relationship between a resource based measure of geodiversity and broad scale biodiversity patterns. Biodivers Conserv 19:2751-2766

Pau S, Dee LE (2016) Remote sensing of species dominance and the value for quantifying ecosystem services. Remote Sense Ecol Conserv 2:141-151

Pavelsky TM, Zarnetske JP (2017) Rapid decline in river icings detected in arctic Alaska: implications for a changing hydrologic cycle and river ecosystems. Geophys Res Lett 44(7):2016GL072397. https://doi.org/10.1002/2016GL072397

Peacock J, Baker TR, Lewis SL, Lopez-Gonzalez G, Phillips OL (2007) The RAINFOR database: monitoring forest biomass and dynamics. J Veg Sci 18:535-542

Petorelli N, Laurance WF, O'Brien TG, Wegmann M, Nagendra H, Turner W (2014) Satellite remote sensing for applied ecologists: opportunities and challenges. J Appl Ecol 51:839-848 
Pourmokhtarian A, Driscoll CT, Campbell JL, Hayhoe K, Stoner AMK (2016) The effects of climate downscaling technique and observation dataset on modeled ecological responses. Ecol Appl 26:1321-1337

Radford AE (1981) Natural heritage: classification, inventory and information. University of North Carolina Press, Chapel Hill

Rahbek C (2005) The role of spatial scale and the perception of large-scale species-richness patterns. Ecol Lett 8:224-239

Record S, Charney ND (2016) Modeling species ranges. Chance 29:31-37

Record S, Fitzpatrick MC, Finley AO, Veloz S, Ellison AM (2013) Should species distribution models account for spatial autocorrelation? A test of model projections across eight millennia of climate change. Glob Ecol Biogeogr 22:760-771

Record S, McCabe T, Baiser B, Ellison AME (2018) Identifying foundation species in North American forests using long-term data on ant assemblage structure. Ecosphere 9:e01239

Richerson PJ, Lum K (1980) Patterns of plant species and diversity in California: relation to weather and topography. Am Nat 116:504-536

Rienecker MM, Suarez MJ, Gelaro R, Todling R, Bacmeister J, Liu E, Bosilovich MG, Schubert SD, Takacs L, Kim GK, Bloom S (2011) MERRA: NASA's modern-era retrospective analysis for research applications. J Clim 24:3624-3648

Rignot E, Mouginot J, Scheuchl B (2011) Ice flow of the Antarctic ice sheet. Science 333:1427-1430

Riley SJ, DeGloria SD, Elliot R (1999) A terrain ruggedness index that quantifies topographic heterogeneity. Intermountain J Sci 5:23-27

Robert L. Pressey, Mar Cabeza, Matthew E. Watts, Richard M. Cowling, Kerrie A. Wilson, (2007) Conservation planning in a changing world. Trends in Ecology \& Evolution 22(11):583-592

Robinson N, Regetz J, Guralnick RP (2014) EarthEnv-DEM90: a nearly global, void-free, multiscale smoothed, 90m digital elevation model from fused ASTER and SRTM data. ISPRS J Photogramm 87:57-67

Rowan LC, Mars JC (2003) Lithologic mapping in the Mountain Pass, California area using advanced spaceborne thermal emission and reflection radiometer (ASTER) data. Remote Sens Environ 84:350-366

Sala OE, Chapin FS, Armesto JJ, Berlow E, Bloomfield J, Dirzo R, Huber-Sanwald E, Huenneke LF, Jackson RB, Kinzig A, Leemans R, Lodge DM, Mooney HA, Oesterheld M, Poff NL, Sykes MT, Walker BH, Walker M, Wall DH (2000) Global biodiversity scenarios for the year 2100. Science 287:1770-1774

Sang-Ho Yun, Kenneth Hudnut, Susan Owen, Frank Webb, Mark Simons, Patrizia Sacco, Eric Gurrola, Gerald Manipon, Cunren Liang, Eric Fielding, Pietro Milillo, Hook Hua, Alessandro Coletta, (2015) Rapid Damage Mapping for the 2015 7.8 Gorkha Earthquake Using Synthetic Aperture Radar Data from COSMO-SkyMed and ALOS-2 Satellites. Seismological Research Letters 86(6):1549-1556

Serrano E, Ruiz-Flaño P, Arroyo P (2009) Geodiversity assessment in a rural landscape: TiermesCaracena area (Soria, Spain). Memorie desrittive della carta geologica d'Italia 87:173-180

Smith SJ, Edmonds J, Hartin CA, Mundra A, Calvin K (2015) Near-term acceleration in the rate of temperature change. Nat Clim Chang 5:333-336

Spehn EM, Körner C (2005) A global assessment of mountain biodiversity and its function. In: Huber UM, BugmannMel KM, Reasoner A (eds) Global change and mountain regions. Springer, Dordrecht, pp 393-400

Srivastava DS, Cadotte MW, MacDonald AAM, Marushia RG, Mirotchnick N (2012) Phylogenetic diversity and the functioning of ecosystems. Ecol Lett 15:637-648

Stavros EN, Schimel D, Pavlick R, Serbin S, Swann A, Ducanson L, Fisher JB, Fassnacht F, Ustin S, Dubayah R, Schweiger A (2017) ISS observations offer insights into plant function. Nature Ecol Evol 1:0194

Stein A, Gerstner K, Kreft H (2014) Environmental heterogeneity as a universal driver of species richness across taxa, biomes, and spatial scales. Ecol Lett 17:866-880 
Stendera S, Adrian R, Bonada N, Cañedo-Argüelles M, Hugueny B, Januschke K, Pletterbauer F, Hering D (2012) Hydrobiologia 696:1-28

Still CJ, Pau S, Edwards EJ (2014) Land surface temperature captures thermal environments of C3 and C4 grasses. Glob Ecol Biogeogr 23:286-296

Tedesco M (2014) Remote sensing of the cryosphere. Wiley-Blackwell, Hoboken

Thackeray SJ, Sparks TH, Fredericksen M, Burthe S, Bacon PJ, Bell JR, Botham MS, Brereton TM, Bright PW, Carvalho L, Clutton-Brock T, Dawson A, Edwards M, Elliott JM, Harrington R, Johns D, Jones ID, Jones JT, Leech DI, Roy DB, Scott WA, Smith M, Smithers RJ, Winfield IJ, Wanless S (2010) Trophic level asynchrony in rates of phenological change for marine, freshwater and terrestrial environments. Glob Change Biol 16:3304-3313

Tuanmu M-N, Jetz W (2015) A global, remote sensing-based characterization of terrestrial habitat heterogeneity for biodiversity and ecosystem modeling. Glob Ecol Biogeogr 24:1329-1339

Tukiainen H, Bailey JJ, Field R, Kangas K, Hjort J (2017) Combining geodiversity with climate and topography to account for threatened species richness. Cons Biol 31:364-375

Tuomisto H, Ruokolainen K, Aguilar M, Sarmiento A (2003) Floristic patterns along a 43-km long transect in an Amazonian rainforest. J Ecol 91:743-756

Turner W (2014) Sensing biodiversity. Science 346:301-302

van der Werff H, van der Meer F (2016) Sentinel-2A MSI and Landsat 8 OLI provide data continuity for geological remote sensing. Remote Sens 8(11):883

Veloz SD, Williams JW, Blois JL, Feng H, Otto-Bliesner B, Liu Z (2012) No-analog climates and shifting realized niches during the late quaternary: implications for 21 st-century predictions by species distribution models. Glob Change Biol 18:1698-1713

Vincent WF, Callaghan TV, Dahl-Jensen D, Johansson M, Kovacs KM, Michel C, Prowse T, Reist JD, Sharp M (2011) Ecological implications of changes in the Arctic cryosphere. Ambio 40:87-99

Violle C, Enquist BJ, McGill BJ, Jiang L, Albert CH, Hulshof C, Jung V, Messier J (2012) The return of the variance: intraspecific variability in community ecology. Trends Ecol Evol 27:244-252

Vitousek PM, Aplet G, Turner D, Lockwood JJ (1992) The Mauna Loa environmental matrix: foliar and soil nutrients. Oecologia 89:372-382

Walther G-R, Post E, Convey P, Menzel A, Parmesan C, Beebee TJC, Fromentin J-M, Hoegh Guldberg O, Bairlein F (2002) Ecological responses to recent climate change. Nature 416:389-395

Weber F, Nixon D, Hurley J (2003) Semi-automated classification of river ice types on the Peace River using RADARSAT-1 synthetic aperture radar (SAR) imagery. Can J Civil Eng 30:11-27

Williams RS (2012) Introduction — changes in the Earth's cryosphere and global environmental change in the earth system. In: Williams RS, Ferrigno JG (eds) State of the earth's cryosphere at the beginning of the $21^{\text {st }}$ century - glaciers, global snow cover, floating ice, and permafrost and periglacial environments: U.S. Geological Survey Professional Paper 1386-A. U.S. Geological Survey, Reston, p 23

Williams JW, Jackson ST (2007) Novel climates, no-analog communities, and ecological surprises. Front Ecol Environ 5:475-482

Wilson AM, Jetz W (2016) Remotely sensed high-resolution global cloud dynamics for predicting ecosystem and biodiversity distributions. PLoS Biol 14:1-20

Wood J (1996) Scale-based characterisation of digital elevation models. Innovat GIS 3:163-175

Yachi S, Loreau M (1999) Biodiversity and ecosystem productivity in a fluctuating environment: the insurance hypothesis. P Natl Acad Sci USA 96:1463-1468

Yoshikawa K, Hinzman LD, Kane DL (2007) Spring and Aufeis (icing) hydrology in Brooks Range, Alaska. J Geophys Res-Biogeosci 112:G04S43

Yu H, Chin M, Bian H, Yuan T, Prospero JM, Omar AH, Remer LA, Winker DM, Yang Y, Zhang Y, Zhang Z (2015) Quantification of trans-Atlantic dust transport from seven-year (2007-2013) record of CALIPSO LIDAR measurements. Remote Sens Environ 15:232-249

Zarnetske PL, Skelly DK, Urban MC (2012) Biotic multipliers of climate change. Science 336:15-30 
Zarnetske PL, Baiser B, Strecker A, Record S, Belmaker J, Tuanmu M-N (2017) The interplay between landscape structure and biotic interactions. Curr Landscape Ecol Rep 2:12-29

Zarnetske PL, Record S, Dahlin K, Read Q, Grady JM, Costanza J, Finley AO, Gaddis K, Hobbi M, Latimer A, Malone S, Ollinger S, Pau S, Turner W, Wilson A (2019) Connecting biodiversity and geodiversity with remote sensing across scales. Glob Ecol Biogeog 28:548-556.

Zwally HJ, Li J, Brenner AC, Beckley M, Cornejo HG, Di Marzio J, Giovinetto MB, Neumann TA, Robbins J, Saba JL, Yi D, Wang W (2011) Greenland ice sheet mass balance: distribution of increased mass loss with climate warming; 2003-07 versus 1992-2002. J Glaciol 57:88-102

Open Access This chapter is licensed under the terms of the Creative Commons Attribution 4.0 International License (http://creativecommons.org/licenses/by/4.0/), which permits use, sharing, adaptation, distribution and reproduction in any medium or format, as long as you give appropriate credit to the original author(s) and the source, provide a link to the Creative Commons license and indicate if changes were made.

The images or other third party material in this chapter are included in the chapter's Creative Commons license, unless indicated otherwise in a credit line to the material. If material is not included in the chapter's Creative Commons license and your intended use is not permitted by statutory regulation or exceeds the permitted use, you will need to obtain permission directly from the copyright holder. 